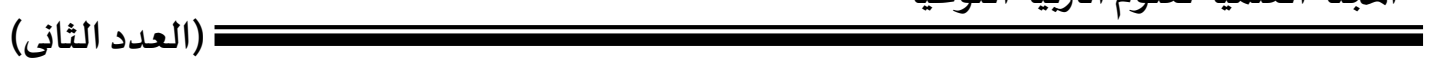

\title{
Prickly pear, Lettuce, Marrow Seeds and Their Blend as Used to lower The Cholesterol in Albino Rats
}

\author{
* Fatma EL-Zahraa Amin El-Sherif, \\ * Dr.Magda Kamel El Shaer, and \\ **Hammam Mohamed Wajeh El-Tantawy \\ * Nutrition and Food Science Dept., Home Economics Faculty, Menoufia University,
}

\begin{abstract}
This study was conducted to investigate the protective effect (at level $7.5 \%$ of marrow vegetable, lettuce seed, prickly pear seeds) and mixture of them at 1:1:1 ratio on liver and kidney functions, blood lipid profiles and blood sugar in rats fed with diets contain height level of cholesterol.

Thirty mature albino male rats weighing $150 \pm 5 \mathrm{~g}$. B.WT. each, were divided into sex equal groups, The first group kept as a control-ve group, while the others five groups fed on diet containing high level of cholesterol for 3 weeks to obtain hypercholesterolemic rats. At the end of experimental period (28 days), animals were sacrificed. Blood samples were collected to determine the biochemical analytics: serum total cholesterol (T.C.), triglycerides (T.G), lipoprotein fractions (HDL-c, LDL-c, and VLDL-c), atherosclerotic index (AI), liver enzymes (AST, ALT and ALP), total bilirubin, urea, uric acid, creatinine and fasting plasma glucose. Moreover, heart, liver and kidneys subjected to for histopathological examination. The obtained results concluded that diets of marrow, lettuce, prickly pear seeds and their mixture caused the improvement of all biochemical analysis.
\end{abstract}

Key words: Marrow seeds, lettuce seeds, prickly pear seeds, hypercholesterolemic, cholesterol, blood lipid profile, liver functions, kidneys functions. 


\section{استخدام بذور التين الثوكي، الخس، الكوسة ومخلوطهم لتقليل مستوى الكولستيرول في الفئر ان البيضاء}

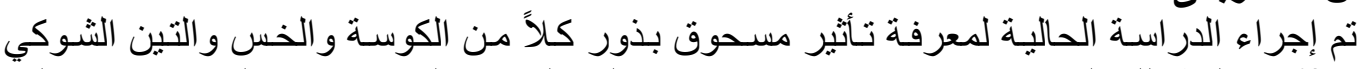

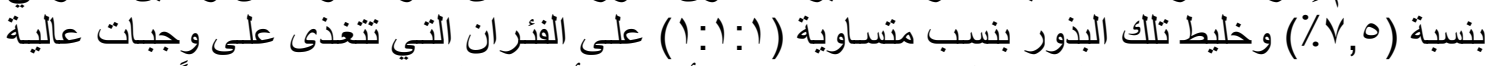

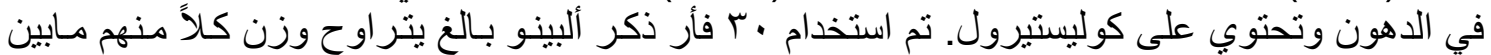

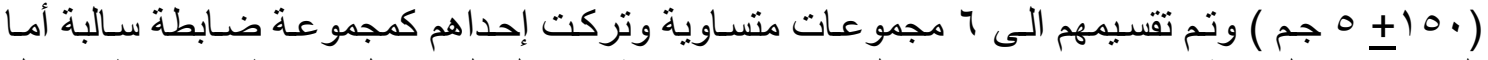

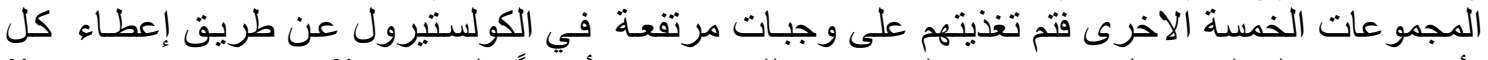

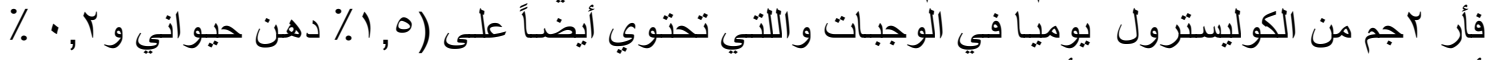

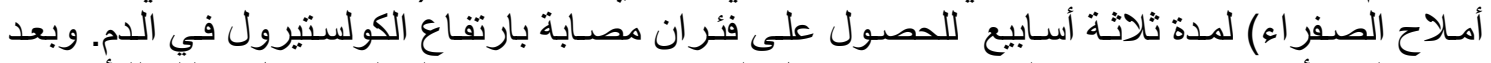

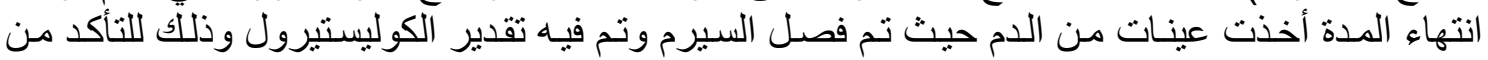

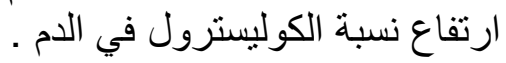

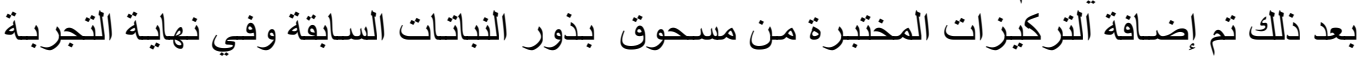

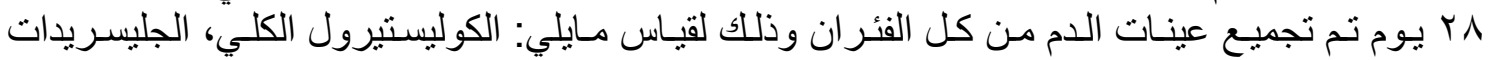

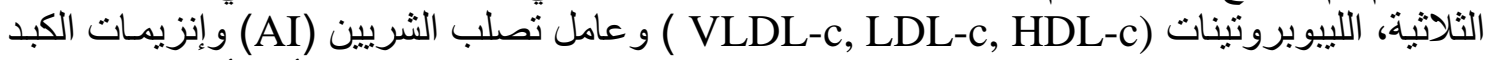

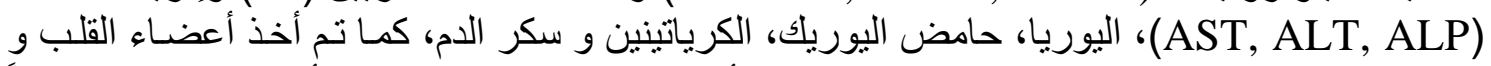

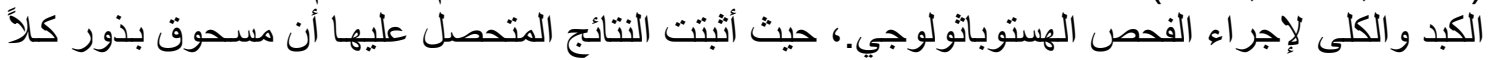

من الكوسه و الخس و التين الثوكي وخليط منهم قد حسنت من كل التحليلات البيوكيميائية السابق ذكرها.

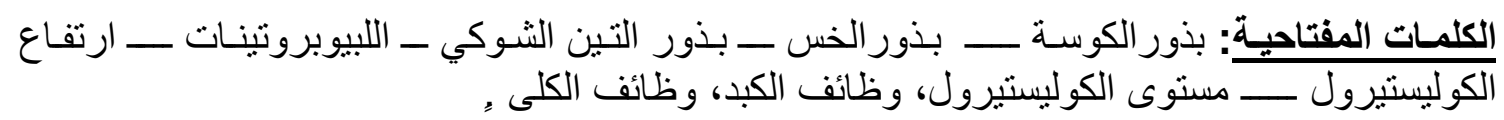




\section{INTRODUCTION:}

Despite remarkable advances in medicine and research, there is an increase in cardiovascular diseases spread Callias (2007). It is one of the leading causes of death worldwide. They are responsible each year of $30 \%$ of mortality in the world. About $75 \%$ of them occur in countries with low and middle incomes. Twenty-five million deaths are expected in 2020 Rachid and Hassan (2007). Hypercholesterolemic is a metabolic condition that determines the onset of chronic degenerative diseases such as atherosclerosis (Devi and Sharma, 2004 and Kim et al. 2008). It is characterized by the elevation of cholesterol and lipid parameters (LDL-cholesterol, triglycerides).

There is hypercholesterolemic when cholesterol (LDL-c) in the blood is higher than the actual needs. The excess not used by the cells then tend to settle against the vessel walls, causing, if not recovered and returned to the liver by HDL-c, obstruction of the arteries, leading to infarction (Callias 2007). Triglycerides are lipid molecules formed in the small intestine from consumed fat. They are also produced in the liver from excess sugar diets. Fats are not soluble in water; triglycerides need to combine with other substances lipoproteins- to be transported throughout the body. Prickly pear seed and corresponding oil were studied. The minerals content $(\mathrm{Ca}, \mathrm{Cu}, \mathrm{Fe}, \mathrm{K}, \mathrm{Mg}, \mathrm{Na}, \mathrm{P}$, $\mathrm{Mn}$ and $\mathrm{Zn}$ ) were analyzed by inductively coupled plasma atomic emission spectrometry. Minerals determined were: Calcium $471.2 \mathrm{mg} / \mathrm{kg}$, potassium $532.7 \mathrm{mg} / \mathrm{kg}$, magnesium $117.3 \mathrm{mg} / \mathrm{kg}$, phosphorus $1,627.5 \mathrm{mg} / \mathrm{kg}$ and natrium $71.3 \mathrm{mg} / \mathrm{kg}$ (Margarita et all., 2011). The fatty acids profile of seed oil from the Opuntia ficus indica were analyzed by gas chromatography (G.C). Linoleic acid was established as the major fatty acid (61.01\%), followed by oleic $(25.52 \%)$ and palmitic (12.23\%) acids. Both myristic, stearic and arachidonic acids were detected in Opuntia ficus indica seed oil in low amounts. As a result, Opuntia. ficus indica seeds are important source of natural fiber and, due to high linoleic acid content, this oil can be used as a nutraceutic agent (Mehmet and Fahadm, 2011).

All types of lettuce do not provide the same nutritional benefits. Iceberg lettuce for example has a high water content and therefore less nutritional value. Most types of lettuce, even ice burg, do provide magnesium. Other types of lettuce also provide vitamin C and beta-carotene Kiple and Kriemhild, (2000).

Marrow vegetable is low in calories with no fat or cholesterol. A 1/2-cup serving of cooked or raw marrows provide significant amounts of dietary fiber, vitamin $\mathrm{A}$, vitamin $\mathrm{C}$, iron and calcium. A diet high in these nutrients may help decrease the risk of several serious medical conditions, including heart diseases, stroke, osteoporosis, cancers, obesity, diabetes, hypertension and high blood cholesterol. The Centers for Disease Control and Prevention Advises that the peel of marrow vegetables as rich in the carotenoid beta-carotene, and should be eaten along with the flesh to get the maximum nutritional benefit. Beta-carotene is powerful antioxidants that can inhibit free radical compounds from damaging cellular tissue and DNA (Michelle and Demand, 2014). 


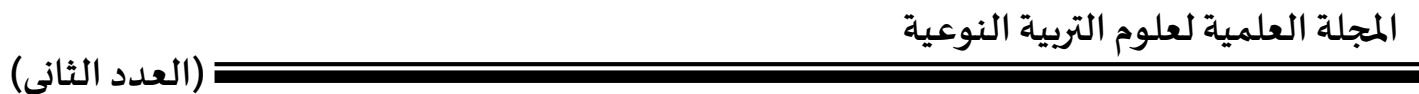

\section{AIM OF THE STUDY:}

The percent study was aimed to examine the effect of marrow, lettuce, prickly pear seeds and their mixture at 1:1:1 on body weight gain, feed intake, feed efficiency ratio, liver function, kidney function, blood glucose, lipids and histological structure of heart, liver and kidney of hypercholesterolemic rats.

\section{MATERIALS AND METHODS:}

\section{Materials:}

Marrow (Cucurbita pepo L.), Lettuce (Lactuca sativa L.) and Prickly pear (Opuntia indica) seeds season (2013) were obtained from local farmers in (Shebin-Elkom, Menoufia Governorate, Egypt), cleaned thoroughly by washing. Then the seeds were dried by sun drying, then in air at the room temperature and ground using a blender (C) MOULINEX into fine powder seeds. Since cholesterol metabolism in rats closely resembles that of human, albino rats recommended to be used for atherosclerosis research (Brave et al. 1994).

Rats: Accordingly thirty (30) Sprague Dawley white male albino rats were used in the present study. All rats were housed in an individual stainless steel cages under controlled condition, diets were introduced to rats in especial non-scattering feeding cups to avoid loss of feed and contamination. Tap water was provided to rats through glass tubes projection through wire cage from inverted bottles supported to one side of the cage. Rats were weighted after 7 days intervals from beginning until end of the experiment.

\section{Methods:}

Experimental design: Thirty (30) (Sprague - Dawley strain) male albino rats were distributed into 6 groups each of 5 rat in which means of rats weight for all groups were nearly equal. All rats were housed in wire cages and fed on the experimental diets for 4 weeks according to the following groups:

The first group: Rats of group 1 fed on the basal diet (control-ve). On the contrary, other five groups (25 rats), were fed first on hypercholesterolemic diet (basal diet of cholesterol $2 \%+1.5 \%$ animal fats $+0.2 \%$ bile salts) for 3 weeks to obtain hypercholesterolemic rats before starting the treatment period, it was prepared according to Hegsted et al., (1941).

Group (1): Control negative group (-ve), in which normal rats were fed on basal diet only for 28 days.

Group (2): Hypercholesterolemic rats were fed on the basal diet only without any treatment (as control+ve).

Group (3): Hypercholesterolemic rats were fed on the basal diet plus $7.5 \%$ of marrow seeds powder.

Group (4): Hypercholesterolemic rats were fed on the basal diet plus $7.5 \%$ of lettuce seeds powder.

Group (5): Hypercholesterolemic rats were fed on the basal diet plus $7.5 \%$ of prickly pear seeds powder.

Group (6): Hypercholesterolemic rats were fed on the basal diet plus $7.5 \%$ of 


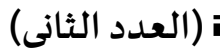

equalized mixture from all seeds powder.

While rats were weighted at the beginning of the experimental then weekly till the end of the experiment was recorded daily.

Diets: The basal diet was prepared according to Reeves et al. (1993). The vitamin mixtures were prepared according to Campbell, (1963). The salt mixtures were prepared according to Muller, A. (1964).

Organ weights: The organs (Liver - Heart- kidney -Spleen - and Lungs) were excised, rinsed in chilled saline solution, then blotted on filter paper, and weighed separately to calculate the absolute and relative organs weight.

\section{Biochemical analysis of blood:}

At the end of the 4 weeks, the animals were anesthetized with diethyl ether. Incisions were made into the abdomen and blood samples were obtained from the portal vein into centrifuge tubes. Plasma was separated by centrifugation at $4000 \mathrm{r}$.p. $\mathrm{m}$ for 10 minutes. The collected samples were analyzed for the biochemical parameters. Enzymatic colorimetric method used to determine, aspartate aminotransferase AST (GOT), alanine aminotransferase ALT (GOT) activities were measured according to method described by Reitman and Frankel (1957). Alkaline phosphates' (ALP) was performed according to the method of Roy (1970) and Belfield and Goldberg (1971). Determination of Cholesterol performed according to Charles et al. (1974), triglycerides according to Fossati and Prencipe (1982), high density lipoprotein cholesterol (HDL) according to Fnedewaid (1972) and Gordon and Amer (1977). Low density lipoprotein cholesterol (LDL-c) and very low density lipoprotein cholesterol (VLDL-c) assessed according to Lee and Nieman (1996). Creatinine was determined according to the method described by Bartles $\boldsymbol{e t}$ al. (1972) and Larsen (1972), urea according to the method described by Fawcett and Soctt (1960), uric acid according to the method described by Barham and Trinder (1972). Serum glucose according to Trinder (1969).

Histological examination: Specimens from (liver, kidneys, and heart) were collected from rats at the end of experimental period, fixed in $10 \%$ neutral buffered formalin (PH 7.5) dehydrated in ethyl alcohol, cleared in xylol and embedded in paraffin 4-6 mm sections which were stained with hematoxyl and eosin according to Carleton et al. (1976).

Statistical analysis: The obtained data were statistically analyzed using computerized SPSS Program. Effect of different treatments were analyzed by one way ANOVA (Analysis of Variance) test using Duncan's Multiple Range Test and $\mathrm{p} \leq 0.05$ was used to indicate significance between different groups (Snedecor and Cochran, 1967).

\section{RESULTS AND DISCUSSION:}

The results in Table (1) showed the effect of feeding with $7.5 \%$ concentration of marrow, lettuce, prickly pear seeds powder and their mixture on body weight gain (BWG), feed intake (FI) and feed efficiency ratio (FER) in 
hypercholesterolemic rats. Data illustrate in hypercholesterolemic rats a gradual increase in relative BWG, FI, and FER when feeding on $7.5 \%$ of marrow, lettuce, prickly pear seeds powder, and their mixture at 1:1:1 ratio . The statistical analysis showed the changes between treatments for BWG, FI, and FER, especially for the seeds mixture group. The hypercholesterolemic rats groups showed loss in body weight that might be as the result of protein wasting due to unavailability of carbohydrates for utilization as an energy source in compared with the control negative group. These results are in agreement with those reported by Baynes and Thorpe (1999). The supplementation of animal diets with $25 \mathrm{~g} / 1 \mathrm{~kg}$ of prickly pear seed oil had no significant effect on body weight gain and digestibility, but caused a decrease in feed conversion efficiency . Opuntia sp. fruits contain high values from important nutrients, such as betalains, amino compounds including taurine, minerals, vitamins, as well as further antioxidants. Also these results are in agreement with those reported by Stintzing et al. (2001).

Table (2) cleared the effect of feeding with $7.5 \%$ concentration of the seeds powder of marrow, lettuce, prickly pear seeds powder and their mixture at 1:1:1 ratio on organs weight $(\mathrm{g})$ of hypercholesterolemic rats. Data illustrated that in hypercholesterolemic rats a gradual increase took place in organs weight. Marrow seed, lettuce seed, prickly pear seed, and mixture from them diets lowered such weights. The statistical analysis showed mostly significant declined between treatments and control (+) group. These results are in agreement with those reported by Kwon et al. (2013).

Table (3) reflects the effect of feeding with $7.5 \%$ concentration of the seeds powder of marrow, lettuce, prickly pear seeds and mixture from them (1:1:1 ratio) on fasting plasma glucose $(\mathrm{mg} / \mathrm{dl})$ of hypercholesterolemic rats. Results illustrate a pronounced decrease of blood glucose levels followed feeding on marrow, lettuce, prickly pear seeds powder and the combination of all. Data proved the desirable effect of feed seeds on blood glucose. Blood glucose was lower in the all supplemented diets compared to control (+ve) group. Group 4 (lettuce seeds) revealed the lowest values compared to others groups. These results are in agreement with those reported by Wolfram et al. (2003); they found that the prickly pear owns well-known antdiabetic and lipid lowering properties. Also these results are in agreement with those reported by Lida Y et al. (2013).

The obtained results in table (4): reflect the effect of marrow, lettuce, prickly pear seeds powder and their mixture on serum levels of total cholesterol $(\mathrm{mg} / \mathrm{dl})$ and triglycerides $(\mathrm{mg} / \mathrm{dl})$ in hypercholesterolemic rats. Data revealed pronounced decreases of serum (T.C) and (TG), when feeding rats on mixture of all seeds. These results are in agreement with those reported by Ramadan and Mörsel (2003). They found the evidence that cactus pear reduces cholesterol levels in human and modify LDL concentration. Also, Ennouri et al. (2006); Rodriguez-Fragoso et al. (2008) and Leo de et al., (2010) reported that among the many uses; cladodes (leaves) of cactus pear have been reported to be 
utilized for their hypolipidemic properties. Lida Y. et al., (2013); found that serum cholesterol reduced significantly whereas other parameters did not change when used lettuce (Lactuca sativa L.).

Results in Table (5) show the effect of marrow, lettuce, prickly pear seeds powder and their mixture on high density lipoprotein cholesterol (HDL-c) and low density lipoprotein cholesterol (LDL-c) in hypercholesterolemic rats. Data revealed pronounced decreases in serum HDL-c and LDL-c, when rats fed on mixture of all seeds powder LDL -c declined, while HDL-c was raised. These results are in agreement with those reported by Ramadan and Mörsel (2003); they found the evidence that cactus pear reduces cholesterol levels in human and modify LDL-c content. Abuelgassim and Al-showayman (2012) reported that the atherogenic rats supplemented with vegetable marrow seeds showed significant decreases $(\mathrm{p} \leq 0.001)$ in their serum concentrations of total cholesterol and LDL-c as they dropped from $4.89 \mathrm{mmol} / \mathrm{L}$ to $2.55 \mathrm{mmol} / \mathrm{L}$ and from 3.33 $\mathrm{mmol} / \mathrm{L}$ to $0.70 \mathrm{mmol} / \mathrm{L}$, respectively. Also, serum concentrations of HDL-C were significantly elevated in the same group. Although, atherogenic rats supplemented with 2\% arginine showed significant increase in serum concentration of HDL-c, no significant changes were observed in their serum concentrations of total cholesterol and LDL-c. The results in Table (5) show that treatment of atherogenic rats with mixture from all seeds significantly decreased serum concentrations of (TC.) and LDL-c. The obtained data suggested that such diets supplementation has a protective effect against atherogenic rats and this protective effect was not attributed to the possible high arginine concentration in vegetable marrow but to the effect of all seed powders .

In Table (6) shows the effect of marrow, lettuce, prickly pear seeds powder and mixture of all powder seeds on very low density lipoprotein cholesterol (VLDL-c) and atherogenic (AI) of hypercholesterolemic rats. Data revealed pronounced decreases of serum VLDL-c and AI, when rats fed on mixture of all powder seeds. Results are in agreement with those reported by Jowhary et al. (2013) that comparing to the high cholesterol group, formation of arthrosclerosis by lettuce seeds extract decreased. It can be said that lettuce seeds extract effectively prevents from the advance of arthrosclerosis platelets.

Data in Table (7) shows the effect of feeding with $7.5 \%$ concentration for the seeds powder of marrow, lettuce, prickly pear seeds and their mixture at 1:1:1 ratio on serum levels of asparate amino trans-aminase (AST), alanin amino transferase (ALT), alkaline phosphatase (ALP) and (AST/ALT) in hypercholesterolemic rats. AST level in hypercholesterolemic rats fed on the basal diet was $187.00 \pm 4.67 \mathrm{U} / \mathrm{L}$. The decrease of aspartate amino transferase (AST) level and alanine amino transferase (ALT) levels were recorded specially for marrow seeds diet. Alkaline phosphates (ALP), improved in particular when rats fed on lettuce seeds. These results in Table 7 agreed with that of Ncibi $\boldsymbol{e t}$ al. (2008). Prickly pear stem extract protected the liver and decreases the toxicity induced by organ phosphorous pesticide. 
Table (8) cleared the effect of feeding with $7.5 \%$ concentration from the seeds powder of marrow, lettuce, prickly pear seeds and mixture from them at 1:1:1 ratio on serum levels of kidney functions parameters $(\mathrm{mg} / \mathrm{dl})$ in hypercholesterolemic rats. Serum creatinine level of rats fed control (+) diet was $0.40 \pm 0.087 \mathrm{mg} / \mathrm{dl}$. Marked decrease of serum creatinine was observed with the feeding of hypercholesterolemic rats on marrow, lettuce, prickly pear seeds, and mixture from all seeds. Urea and uric acid showed a parlayed decreases when rats fed on mentioned seeds diets. But the best transactions recorded when rats fed on the marrow seeds. Benjamin - (1922) investigated the effects of cucurbita pepo seeds on kidney function. Vegetable marrow diets decreased pronouncedly the levels of urea, cratinine and uric acid in serum.

In present work photos (1-18) indicated that supplementing diets with seeds improved heart, liver and kidneys structures. Anyhow microscopically, heart, liver and kidney of rats from control

(-ve) group showed normal structures (Photo 1, 7 and 13). While, the hypercholesterolemic rats from control (+ve) group showed atrophy and vacuolations in heart, liver and kidney. While mean, heart, liver and kidney of rat from all groups showed no histopathological changes indicating regaining of original structure.

Table (1): Effect of marrow, lettuce, prickly pear seeds powder and their mixture on body weight gain (BWG), feed intake (FI) and feed efficiency atio (FER) of hypercholesterolemic rats

\begin{tabular}{|c|c|c|c|c|c|c|}
\hline $\begin{array}{l}\text { Parameters } \\
\text { Groups }\end{array}$ & $\begin{array}{c}\text { BWG } \\
\text { g/day } \\
\text { Mean } \pm \\
\text { SD }\end{array}$ & $\begin{array}{c}\text { Change } \\
\%\end{array}$ & $\begin{array}{c}\text { FI } \\
\text { g/day } \\
\text { Mean } \pm \\
\text { SD }\end{array}$ & $\begin{array}{c}\text { Change } \\
\%\end{array}$ & $\begin{array}{c}\text { FER } \\
\text { Mean } \pm \\
\text { SD }\end{array}$ & $\begin{array}{c}\text { Change } \\
\%\end{array}$ \\
\hline $\mathbf{G}_{1}(-\mathbf{v e})$ & $\begin{array}{c}0.25^{\mathrm{c}} \pm \\
0.02\end{array}$ & -26.47 & $\begin{array}{c}10.77^{\mathrm{e}} \pm \\
1.50\end{array}$ & -14.59 & $\begin{array}{c}0.023^{\mathrm{ab}} \pm \\
0.001\end{array}$ & -14.81 \\
\hline $\mathbf{G}_{2}(+\mathbf{v e})$ & $\begin{array}{c}0.34^{\mathrm{a}} \pm \\
0.03\end{array}$ & $====$ & $\begin{array}{c}12.61^{\mathrm{a}}+ \\
1.80\end{array}$ & $====$ & $\begin{array}{r}0.027^{\mathrm{a}} \\
+0.003 \\
\end{array}$ & $====$ \\
\hline $\mathbf{G}_{\mathbf{3}}$ & $\begin{array}{c}0.28^{\mathrm{b}} \pm \\
0.009\end{array}$ & -17.64 & $\begin{array}{l}11.90^{\mathrm{bc}} \\
\pm 2.01 \\
\end{array}$ & -5.63 & $\begin{array}{c}0.024^{\mathrm{ab}} \pm \\
0.002\end{array}$ & -14.81 \\
\hline $\mathbf{G}_{4}$ & $\begin{array}{c}0.26^{\mathrm{bc}} \pm \\
0.008\end{array}$ & -23.52 & $\begin{array}{l}11.46^{\mathrm{cd}} \\
+1.22\end{array}$ & -9.11 & $\begin{array}{c}0.023^{\mathrm{ab}} \pm \\
0.009\end{array}$ & -14.81 \\
\hline $\mathbf{G}_{5}$ & $\begin{array}{l}0.26^{\mathrm{bc}} \\
\pm 0.03 \\
\end{array}$ & -23.52 & $\begin{array}{l}11.04^{\mathrm{de}} \\
\pm 1.31 \\
\end{array}$ & -12.45 & $\begin{array}{c}0.023^{\mathrm{ab}} \pm \\
0.008\end{array}$ & -12.96 \\
\hline $\mathbf{G}_{6}$ & $\begin{array}{c}0.21^{\mathrm{d}} \pm \\
0.006\end{array}$ & -38.23 & $\begin{array}{l}12.14^{\mathrm{ab}} \\
\pm 1.52 \\
\end{array}$ & -3.72 & $\begin{array}{r}0.017^{\mathrm{b}} \\
+0.004 \\
\end{array}$ & -37.03 \\
\hline LSD 0.05 & \multicolumn{2}{|c|}{0.020} & \multicolumn{2}{|c|}{0.541} & \multicolumn{2}{|c|}{0.005} \\
\hline
\end{tabular}

Values under the same column bearing letters are average of three replicates $a, b$, $c, d, e \& f$ means unlike differences superscript are significantly differences at $(\mathrm{P} \leq 0.05)$. 
Table (2): Effect of marrow, lettuce, prickly pear seeds powder and their mixture on organs weight $(\mathrm{g})$ of hypercholesterolemic rats

\begin{tabular}{|c|c|c|c|c|c|c|c|c|c|c|}
\hline \multirow[b]{2}{*}{$\begin{array}{l}\text { Parameters } \\
\text { Groups }\end{array}$} & \multicolumn{10}{|c|}{ Organ's weight $(\mathrm{g})$} \\
\hline & 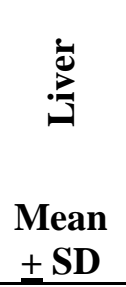 & 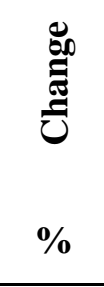 & 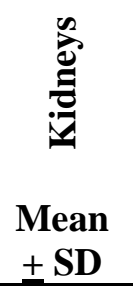 & 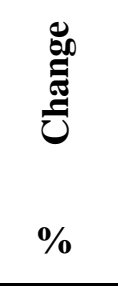 & 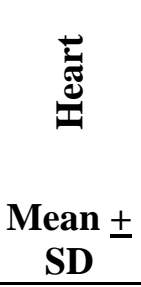 & 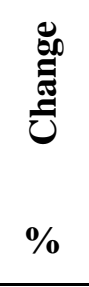 & $\begin{array}{c}\stackrel{20}{60} \\
\Xi \\
\text { Mean } \\
+ \text { SD }\end{array}$ & 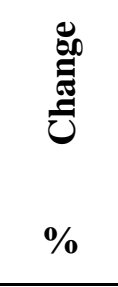 & $\begin{array}{l}\frac{\tilde{d}}{\frac{d}{2}} \\
\text { की } \\
\text { Mean } \\
+ \text { SD }\end{array}$ & $\begin{array}{l}\stackrel{\Xi}{E} \\
\stackrel{\Xi}{E} \\
\%\end{array}$ \\
\hline G1 (-ve) & $\begin{array}{c}4.90^{\mathrm{d}} \pm \\
1.19\end{array}$ & 52.15 & $\begin{array}{c}1.18^{\mathrm{b}} \pm \\
0.08\end{array}$ & 23.37 & $\begin{array}{l}0.64^{\mathrm{c}} \pm \\
0.001\end{array}$ & $\begin{array}{c}- \\
25.5 \\
8\end{array}$ & $\begin{array}{c}1.00^{\mathrm{c}} \\
\pm \\
0.012\end{array}$ & -36.71 & $\begin{array}{c}0.48^{\mathrm{b}} \\
\pm \\
0.009\end{array}$ & -20.00 \\
\hline G2 (+ve) & $\begin{array}{l}10.24^{\mathrm{a}} \\
\pm 1.01\end{array}$ & $==$ & $\begin{array}{c}1.54^{\mathrm{a}} \pm \\
0.11\end{array}$ & $==$ & $\begin{array}{l}0.80^{\mathrm{a}} \pm \\
0.003\end{array}$ & $==$ & $\begin{array}{c}1.58^{\mathrm{a}} \\
\pm \\
0.015\end{array}$ & $==$ & $\begin{array}{c}0.60^{\mathrm{a}} \\
\pm \\
0.004\end{array}$ & $==$ \\
\hline G 3 & $\begin{array}{r}5.72^{b} \\
\pm 0.99\end{array}$ & $\begin{array}{c}- \\
44.14\end{array}$ & $\begin{array}{c}1.28^{\mathrm{b}} \pm \\
0.09\end{array}$ & $\begin{array}{c}- \\
16.88\end{array}$ & $\begin{array}{c}0.76^{\mathrm{b}} \pm \\
0.002\end{array}$ & $\begin{array}{c}- \\
11.6 \\
3 \\
\end{array}$ & $\begin{array}{c}1.16^{\mathrm{b}} \\
\pm \\
0.010 \\
\end{array}$ & -26.58 & $\begin{array}{c}0.42^{\mathrm{c}} \\
\pm \\
0.013 \\
\end{array}$ & -30.00 \\
\hline G 4 & $\begin{array}{r}5.38^{\mathrm{c}} \\
+1.02\end{array}$ & $\begin{array}{c}- \\
47.46\end{array}$ & $\begin{array}{c}1.32^{\mathrm{b}} \pm \\
0.13\end{array}$ & 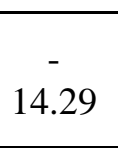 & $\begin{array}{c}0.64^{\mathrm{c}} \pm \\
0.011\end{array}$ & $\begin{array}{c}- \\
25.5 \\
8 \\
\end{array}$ & $\begin{array}{c}1.20^{\mathrm{b}} \\
\pm \\
0.009\end{array}$ & -24.05 & 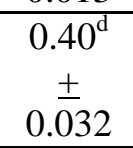 & -33.33 \\
\hline G 5 & $\begin{array}{r}4.78^{\mathrm{d}} \\
\pm 1.03\end{array}$ & $\begin{array}{c}- \\
53.32\end{array}$ & $\begin{array}{c}1.46^{\mathrm{a}} \pm \\
0.05\end{array}$ & 5.19 & $\begin{array}{l}0.64^{\mathrm{c}} \pm \\
0.014\end{array}$ & $\begin{array}{c}- \\
25.5 \\
8 \\
\end{array}$ & $\begin{array}{c}1.20^{\mathrm{b}} \\
\pm \\
0.069\end{array}$ & -24.05 & $\begin{array}{c}0.38^{\mathrm{d}} \pm \\
0.012\end{array}$ & -36.67 \\
\hline G 6 & $\begin{array}{r}5.36^{\mathrm{c}} \\
\pm 1.18\end{array}$ & $\begin{array}{c}- \\
47.66\end{array}$ & $\begin{array}{c}1.24^{\mathrm{b}} \pm \\
0.22\end{array}$ & $\begin{array}{c}- \\
19.48\end{array}$ & $\begin{array}{c}0.60^{\mathrm{d}} \pm \\
0.022\end{array}$ & $\begin{array}{c}- \\
30.2 \\
3\end{array}$ & $\begin{array}{c}1.20^{\mathrm{b}} \pm \\
0.098\end{array}$ & -24.05 & $\begin{array}{c}0.38^{\mathrm{d}} \\
\pm \\
0.014\end{array}$ & -36.67 \\
\hline LSD 0.05 & \multicolumn{2}{|c|}{0.164} & \multicolumn{2}{|c|}{0.128} & \multicolumn{2}{|c|}{0.015} & \multicolumn{2}{|c|}{0.0722} & \multicolumn{2}{|c|}{0.0173} \\
\hline
\end{tabular}

Values under the same column bearing letters are average of three re plicates $a, b, c, d, e \& f$ means unlike differences superscript are significantly differences at $(\mathrm{P} \leq 0.05)$.

Table (3): Effect of marrow, lettuce, prickly pear seeds powder and their mixture on serum glucose $(\mathrm{mg} / \mathrm{dl})$ of hypercholesterolemic rats

\begin{tabular}{c|c|c}
\hline \hline $\begin{array}{c}\text { parameters } \\
\text { Groups }\end{array}$ & $\begin{array}{c}\text { Blood sugar (mg/dl) } \\
\text { Mean } \pm \text { SD }\end{array}$ & $\begin{array}{c}\text { Change } \\
\text { \% }\end{array}$ \\
\hline G 1 (-ve) & $62.00^{\mathrm{f}} \pm 1.19$ & -61.73 \\
\hline G 2 (+ve) & $162.00^{\mathrm{a}} \pm 1.14$ & $=====$ \\
\hline G 3 & $152.50^{\mathrm{b}} \pm 2.23$ & -5.86 \\
\hline G 4 & $68.25^{\mathrm{e}} \pm 2.02$ & -57.87 \\
\hline G 5 & $95.25^{\mathrm{d}} \pm 3.21$ & -41.20 \\
\hline G 6 & $125.60^{\mathrm{c}} \pm 2.33$ & -22.47 \\
\hline LSD 0.05 & \multicolumn{2}{|c}{1.413} \\
\hline \hline
\end{tabular}

Values under the same column bearing letters are average of three replicates $a, b, c, d, e \& f$ means unlike differences superscript are significantly differences at $(\mathrm{P} \leq 0.05)$. 
(العدد الثانى)

Table (4): Effect of marrow, lettuce, prickly pear seeds powder and their mixture on serum levels of total cholesterol $(\mathrm{mg} / \mathrm{dl})$ and triglycerides $(\mathrm{mg} / \mathrm{dl})$ of hypercholesterolemic rats

\begin{tabular}{|c|c|c|c|c|}
\hline Groups & $\begin{array}{c}\text { Total cholesterol } \\
(\mathrm{mg} / \mathrm{dl}) \text { Mean } \pm \text { SD }\end{array}$ & 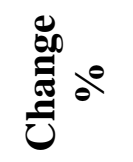 & $\begin{array}{c}\text { Triglycerides } \\
(\mathrm{mg} / \mathrm{dl}) \text { Mean } \pm \mathrm{SD}\end{array}$ & 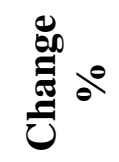 \\
\hline G 1 (-ve) & $95.00^{\mathrm{f}} \pm 1.81$ & -24.60 & $60.00^{\mathrm{f}} \pm 2.10$ & -85.88 \\
\hline G 2 (+ve) & $126.00^{\mathrm{a}} \pm 1.76$ & $====$ & $425.00^{\mathrm{a}} \pm 2.09$ & $====$ \\
\hline G 3 & $114.60^{\mathrm{c}} \pm 1.98$ & -9.05 & $227.60^{c} \pm 2.31$ & -46.44 \\
\hline G 4 & $100.66^{\mathrm{d}} \pm 1.34$ & -20.11 & $171.60^{\mathrm{d}} \pm 2.46$ & -59.62 \\
\hline G 5 & $117.60^{b} \pm 1.43$ & -6.66 & $244.00^{b} \pm 2.51$ & -42.59 \\
\hline G 6 & $98.00^{\mathrm{e}} \pm 1.94$ & -22.22 & $76.40^{\mathrm{e}} \pm 2.98$ & -82.02 \\
\hline LSD 0.05 & 0.483 & & 0.601 & \\
\hline
\end{tabular}

Values under the same column bearing letters are average of three replicates $a, b$, $c, d, e \& f$ means unlike differences superscript are significantly differences at $(\mathrm{P} \leq 0.05)$.

Table (5): Effect of marrow, lettuce, prickly pear seeds powder and their mixture on high density Lipoprotein cholesterol (HDL-c) and low density Lipoprotein cholesterol (LDL-c) of hypercholesterolemic rats

\begin{tabular}{|c|c|c|c|c|}
\hline Groups & $\begin{array}{c}\text { HDL.c } \\
\text { Mean } \pm \text { SD }\end{array}$ & 总 & $\begin{array}{c}\text { LDL.c Mean } \pm \\
\text { SD }\end{array}$ & 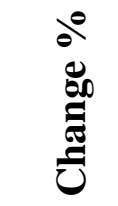 \\
\hline G 1 (-ve) & $60.00^{\mathrm{a}} \pm 1.81$ & +445.45 & $23.00^{\mathrm{d}}+1.31$ & -23.33 \\
\hline G 2 (+ve) & $11.00^{\mathrm{e}} \pm 1.12$ & $=====$ & $30.00^{\mathrm{a}} \pm 2.015$ & $====$ \\
\hline G 3 & $41.58^{\mathrm{d}} \pm 1.43$ & +278.00 & $27.50^{\mathrm{b}} \pm 2.301$ & -8.33 \\
\hline G 4 & $41.34^{\mathrm{d}} \pm 1.37$ & +275.81 & $25.00^{c}+1.23$ & -16.66 \\
\hline G 5 & $44.80^{c} \pm 1.22$ & +307.27 & $24.00^{\mathrm{c}} \pm 1.45$ & -20.00 \\
\hline G 6 & $59.22^{b} \pm 1.15$ & +438.36 & $23.50^{\mathrm{d}} \pm 1.43$ & -21.66 \\
\hline LSD 0.05 & \multicolumn{2}{|c|}{0.466} & \multicolumn{2}{|l|}{0.785} \\
\hline
\end{tabular}

Values under the same column bearing letters are average of three replicates $a, b$, $c, d, e \& f$ means unlike differences superscript are significantly differences at $(\mathrm{P} \leq 0.05)$. 
Table (6): Effect of marrow, lettuce, prickly pear seeds powder and their mixture on very low density Lipoprotein cholesterol (VLDL-c) and atherogenic index (AI) of hypercholesterolemic rats

\begin{tabular}{|c|c|c|c|c|}
\hline Group & $\begin{array}{c}\text { VLDL.c } \\
\text { Mean } \pm \text { SD }\end{array}$ & 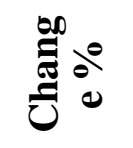 & $\begin{array}{l}\text { Atherogenic index } \\
\text { Mean } \pm \text { SD }\end{array}$ & 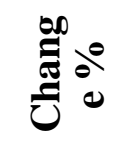 \\
\hline G 1 (-ve) & $12.00^{\mathrm{f}} \pm 0.46$ & -85.88 & $0.614^{b} \pm 0.095$ & -94.12 \\
\hline G 2 (+ve) & $85.00^{\mathrm{a}} \pm 1.62$ & $====$ & $10.45^{\mathrm{a}} \pm 1.79$ & $====$ \\
\hline G 3 & $45.52^{c} \pm 1.43$ & -46.44 & $1.76^{b} \pm 0.059$ & -83.16 \\
\hline G 4 & $34.32^{\mathrm{d}} \pm 1.42$ & -59.62 & $1.43^{b} \pm 0.092$ & -86.31 \\
\hline G 5 & $48.80^{b} \pm 2.45$ & -42.58 & $1.625^{b} \pm 0.102$ & -84.45 \\
\hline G 6 & $15.28^{\mathrm{e}} \pm 1.92$ & -82.02 & $0.655^{\mathrm{b}} \pm 0.043$ & -93.73 \\
\hline LSD 0.05 & 1.19 & & 1.272 & \\
\hline
\end{tabular}

Values under the same column bearing letters are average of three replicates $a, b$, $c, d, e \& f$ means unlike differences superscript are significantly differences at $(\mathrm{P} \leq 0.05)$

Table (7): Effect of marrow, lettuce, prickly pear seeds powder and their mixture on serum levels of aspertate amino transaminase (AST), alanin amino transferase (ALT), alkaLine phosphatase (ALP) and (AST/ALT) of hypercholesterolemic rats

\begin{tabular}{|c|c|c|c|c|c|c|c|c|}
\hline $\begin{array}{l}\text { Parameters } \\
\text { Groups }\end{array}$ & $\begin{array}{c}\text { AST } \\
(\text { U/L) } \\
\text { Mean } \pm \\
\text { SD }\end{array}$ & $\underbrace{\infty}_{0}$ & $\begin{array}{l}\text { ALT } \\
(\mathbf{U} / \mathbf{L}) \\
\text { Mean } \\
\pm \text { SD }\end{array}$ & 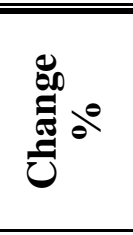 & $\begin{array}{c}\text { ALP } \\
(\mathbf{U} / \mathbf{L}) \\
\text { Mean } \pm \\
\text { SD }\end{array}$ & 包 & $\begin{array}{c}\text { AST/A } \\
\text { LT } \\
\text { (U/L) } \\
\text { Mean } \pm \\
\text { SD } \\
\end{array}$ & 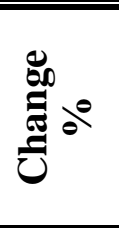 \\
\hline G 1 (-ve) & $\begin{array}{c}101.00^{\mathrm{f}} \\
+2.19\end{array}$ & -45.99 & $\begin{array}{l}32.00^{\mathrm{f}} \\
\pm 1.94\end{array}$ & -63.63 & $\begin{array}{l}122.00^{\mathrm{f}} \\
\pm 1.55\end{array}$ & -57.34 & $\begin{array}{l}3.16^{\mathrm{b}} \\
\pm 0.98\end{array}$ & $\stackrel{+}{44.88}$ \\
\hline G $2(+v e)$ & $\begin{array}{c}187.00^{\mathrm{a}} \pm \\
4.67\end{array}$ & $====$ & $\begin{array}{l}88.00^{\mathrm{a}} \\
\pm 2.48 \\
\end{array}$ & $===$ & $\begin{array}{c}286.00^{\mathrm{a}} \\
\pm 1.27 \\
\end{array}$ & $====$ & $\begin{array}{l}2.13^{\mathrm{f}} \\
\pm 0.89 \\
\end{array}$ & $====$ \\
\hline G 3 & $\begin{array}{l}119.00^{\mathrm{d}} \\
\pm 1.62 \\
\end{array}$ & -36.36 & $\begin{array}{l}34.30^{\mathrm{e}} \\
\pm 1.79\end{array}$ & -61.02 & $\begin{array}{r}222.75^{\mathrm{b}} \\
\pm 1.77\end{array}$ & -22.11 & $\begin{array}{l}3.47^{\mathrm{a}} \\
\pm 1.01\end{array}$ & $\stackrel{+}{+} 2.91$ \\
\hline G 4 & $\begin{array}{c}142.60^{c} \pm \\
1.41\end{array}$ & -23.74 & $\begin{array}{l}48.25^{\mathrm{c}} \\
\pm 1.23\end{array}$ & -45.17 & $\begin{array}{c}124.6^{\mathrm{e}} \pm \\
1.88\end{array}$ & -56.43 & $\begin{array}{l}2.95^{\mathrm{c}} \\
\pm 0.97\end{array}$ & $\stackrel{+}{38.50}$ \\
\hline G 5 & $\begin{array}{c}104.25^{\mathrm{e}} \pm \\
2.10\end{array}$ & -44.25 & $\begin{array}{l}42.60^{\mathrm{d}} \\
\pm 2.42\end{array}$ & -51.59 & $\begin{array}{c}143.00^{\mathrm{d}} \\
\pm 1.99\end{array}$ & -50.00 & $\begin{array}{l}2.45^{\mathrm{e}} \\
\pm 1.09\end{array}$ & $\begin{array}{c}+ \\
57.75\end{array}$ \\
\hline G 6 & $\begin{array}{l}152.75^{\mathrm{b}} \\
\pm 3.32\end{array}$ & -18.32 & $\begin{array}{l}55.40^{\mathrm{b}} \\
\pm 1.66\end{array}$ & -37.05 & $\begin{array}{l}162.20^{\mathrm{c}} \\
\pm 1.44\end{array}$ & -43.29 & $\begin{array}{l}2.76^{\mathrm{d}} \\
\pm 0.79\end{array}$ & $\begin{array}{c}+ \\
29.60\end{array}$ \\
\hline LSD 0.05 & \multicolumn{2}{|c|}{2.240} & \multicolumn{2}{|c|}{0.862} & \multicolumn{2}{|c|}{0.502} & \multicolumn{2}{|c|}{0.188} \\
\hline
\end{tabular}

Values under the same column bearing letters are average of three replicates $a, b$, $\mathrm{c}, \mathrm{d}$, e \& $\mathrm{f}$ means unlike differences superscript are significantly differences at $(\mathrm{P} \leq 0.05)$. 
(العدد الثانى)

Table (8): Effect of marrow, lettuce, prickly pear seeds powder and their mixture on serum levels of kidney functions $(\mathrm{mg} / \mathrm{dl})$ of hypercholesterolemic rats

\begin{tabular}{|c|c|c|c|c|c|c|}
\hline Groups & $\begin{array}{c}\text { Urea } \\
(\mathrm{mg} / \mathrm{dl}) \\
\text { Mean } \pm \\
\text { SD }\end{array}$ & 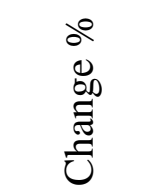 & $\begin{array}{l}\text { Creatinine } \\
\text { Mean } \pm \text { SD }\end{array}$ & 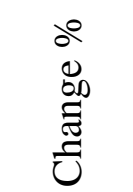 & $\begin{array}{l}\text { Uric Acid } \\
\text { Mean } \pm \\
\text { SD }\end{array}$ & 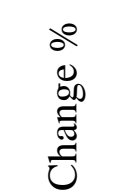 \\
\hline G $1(-v e)$ & $\begin{array}{c}12.00^{\mathrm{e}} \pm \\
0.98^{ \pm}\end{array}$ & -45.45 & $\begin{array}{c}0.30^{\circ} \pm \\
0.09^{ \pm}\end{array}$ & -25.00 & ${ }_{0.01}^{1.00^{\mathrm{c}} \pm}$ & -58.33 \\
\hline G $2(+v e)$ & $\begin{array}{c}22.00^{\mathrm{a}} \pm \\
1.43\end{array}$ & $===$ & $\begin{array}{c}0.40^{\mathrm{a}} \pm \\
0.08^{ \pm}\end{array}$ & $===$ & $\begin{array}{c}2.40^{\mathrm{a}} \pm \\
0.45^{ \pm}\end{array}$ & $====$ \\
\hline G 3 & $\begin{array}{c}13.40^{\mathrm{d}} \pm \\
1.20\end{array}$ & - 39.09 & $\underset{0.02}{0.32^{\mathrm{ab}}} \pm$ & -20.00 & ${ }_{0.07}^{1.50^{\mathrm{bc}}} \pm$ & -37.50 \\
\hline G 4 & $\begin{array}{c}14.00^{\mathrm{c}} \pm \\
1.11\end{array}$ & -36.36 & $\begin{array}{c}0.38^{\mathrm{ab}} \\
0.03\end{array}$ & -5.00 & $\begin{array}{c}2.06^{\mathrm{ab}} \pm \\
0.78\end{array}$ & -14.17 \\
\hline G 5 & $\begin{array}{c}13.80^{\mathrm{c}} \pm \\
1.01\end{array}$ & -37.27 & $\begin{array}{c}0.34^{\mathrm{ab}} \\
0.10\end{array}$ & -15.00 & ${ }_{0.49}^{1.66^{b}} \pm$ & -30.83 \\
\hline G 6 & $\begin{array}{c}19.75^{\circ} \pm \\
1.02\end{array}$ & -10.22 & $\begin{array}{c}0.32^{\mathrm{av}} \pm \\
0.04\end{array}$ & -20.00 & $\begin{array}{c}2.14^{\mathrm{av}} \pm \\
0.43\end{array}$ & -10.83 \\
\hline LSD 0.05 & \multicolumn{2}{|c|}{0.308} & \multicolumn{2}{|c|}{0.060} & \multicolumn{2}{|c|}{0.518} \\
\hline
\end{tabular}

Values under the same column bearing letters are average of three replicates $a, b$, $\mathrm{c}, \mathrm{d}$, e \& f means unlike differences superscript are significantly differences at $(\mathrm{P} \leq 0.05)$.

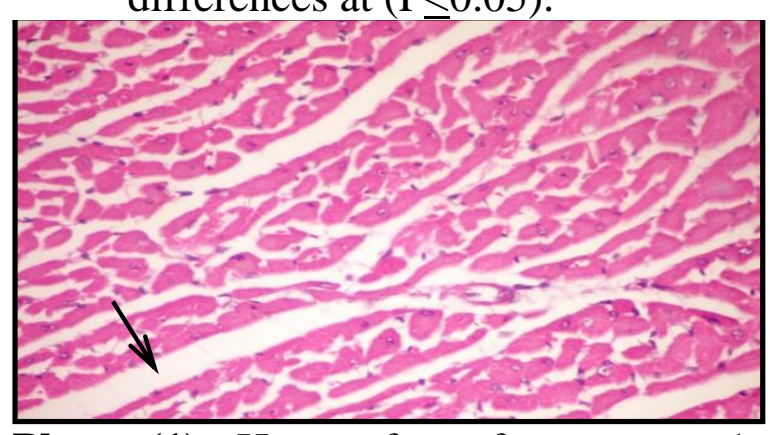

Photo (1): Heart of rat from group 1 (Control negative) showing normal muscle fibers (arrow) (H\&E X 400).

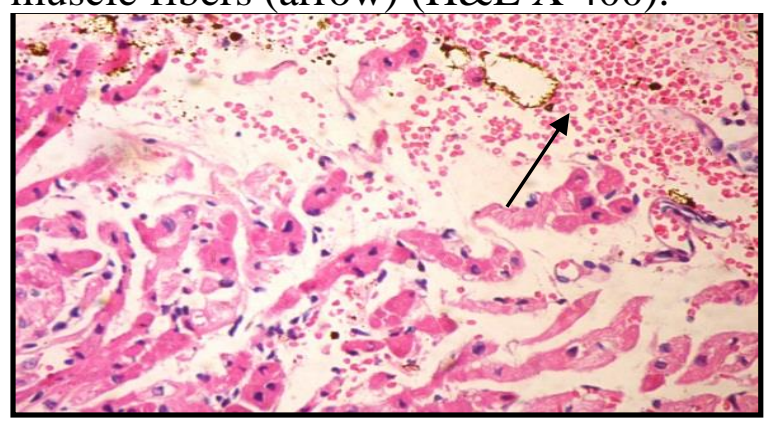

Photo (3): Heart of rat from group 3(Marrow seed $7.5 \%$ ) showing diffuse hemorrhagic areas (arrow) (H\&E X 400).

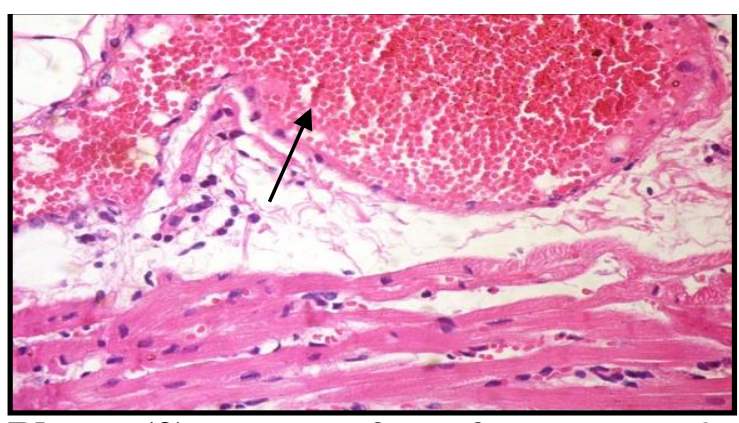

Photo (2): Heart of rat from group 2 (Control positive) showing congested blood vessel (arrow) (H\&E X 400).

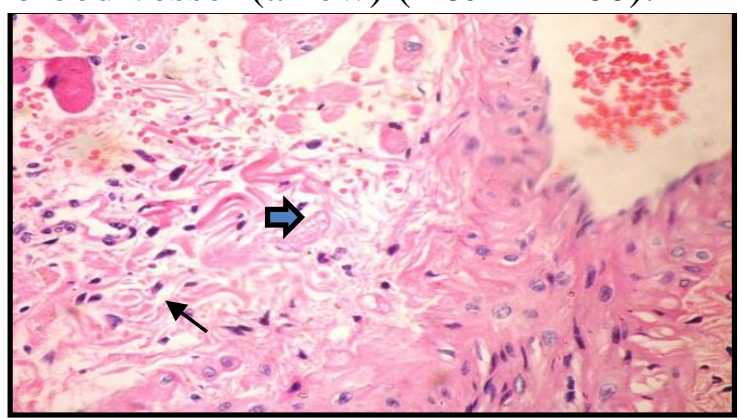

Photo (4): Heart of rat from group 4 (Lettuce seeds $7.5 \%$ ) showing focal area of muscle halitosis' (arrow) infiltrated with hemorrhage (arrow head) (H\&E X 400). 
المجلة العلمية لعلوم التربية النوعية
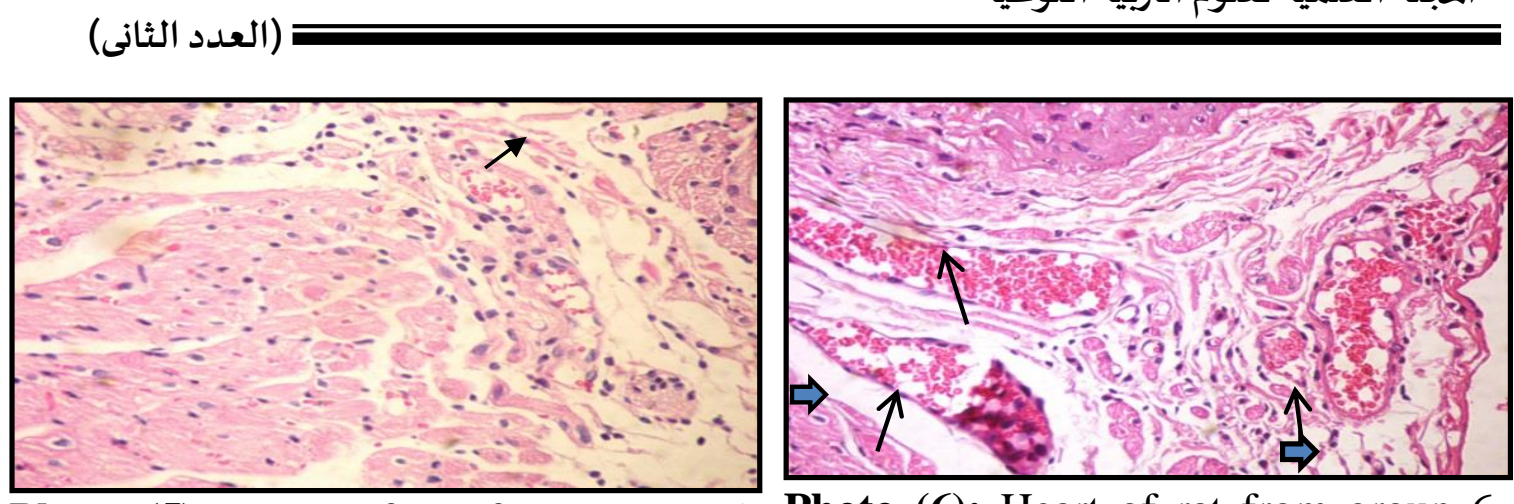

Photo (5): Heart of rat from group 5 (Prickly pear seeds 7.5\%) showing scattered leucocytes cells infiltration (arrow) (H\&E X 400).

Photo (6): Heart of rat from group 6 (Mixture of all seeds) showing severely congested blood vessels (arrows) with per vascular edema (arrow head) (H\&E X 400)
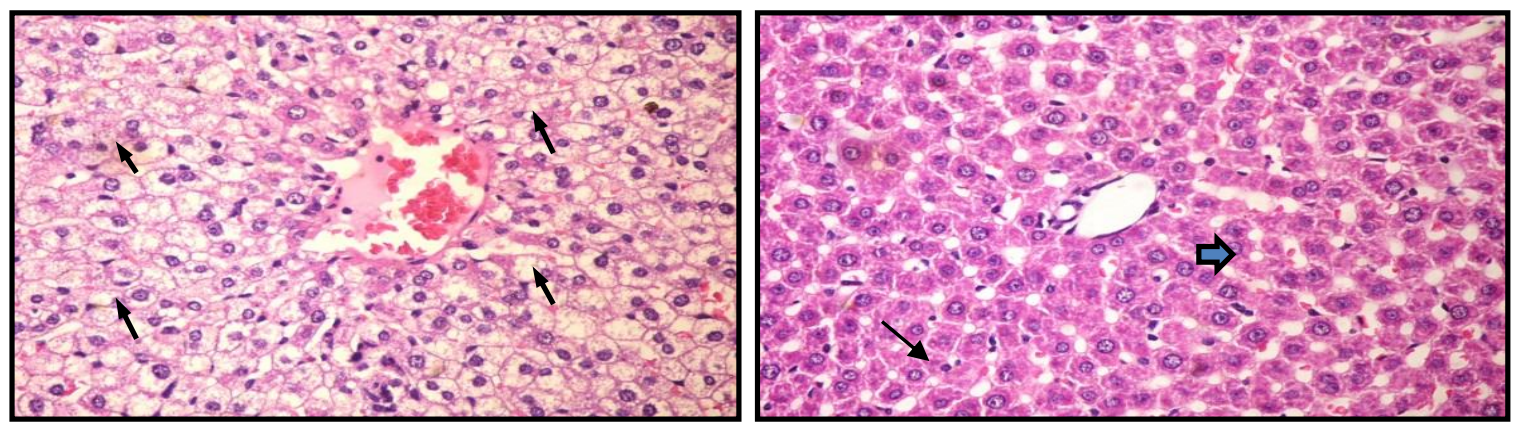

Photo (8): Liver of rat from group 2 (Control positive) showing vacuolar degeneration of most hepatocytes (H\&E X 400).

Photo (7): Liver of rat from group 1 (Control negative) showing apparently healthy hepatocytes (arrow) and blood sinusoids (arrow head) (H\&E X 400).

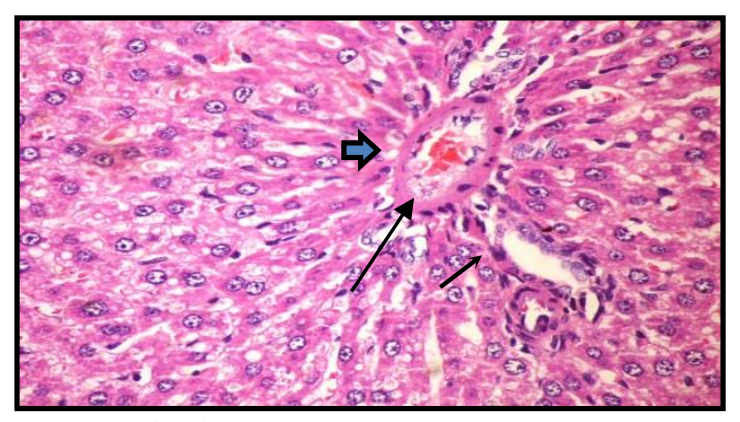

Photo (10): Liver of rat from group 4 (Lettuce seeds7.5\%) showing normal portal tract with normal bile duct (arrow) and hepato portal blood vessel (arrow head) (H\&E X 400).

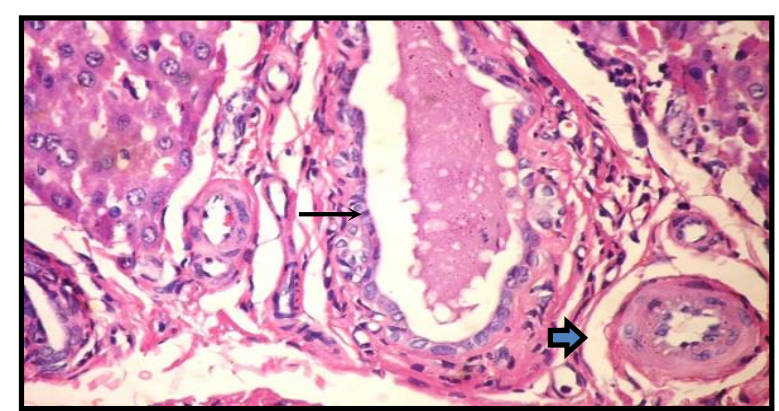

Photo (9): Liver of rat from group 3 (Marrow seed 7.5\%) showing hyperplasia in the bile duct (arrow) with formation of newly formed bile ductules (arrow head) (H\&E X 400). 
المجلة العلمية لعلوم التربية النوعية

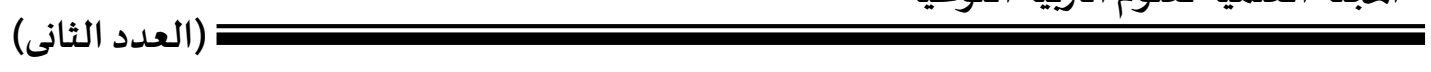

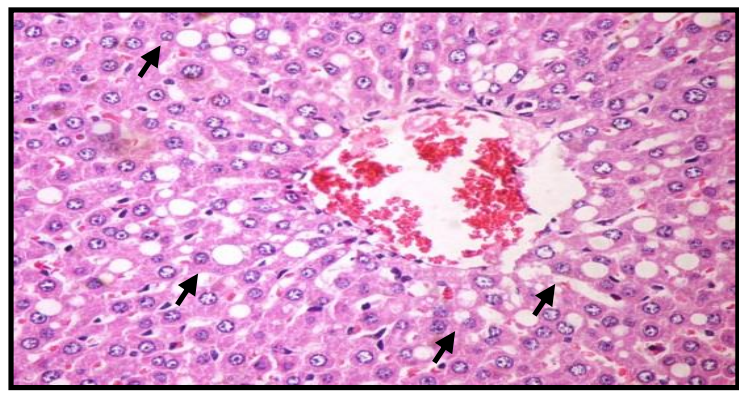

Photo (12): Liver of rat from group 6 (Mixture of all seeds 7.5\%) showing scattered fatty degenerate $d$ hepatic cells (arrows) (H\&E X 400).

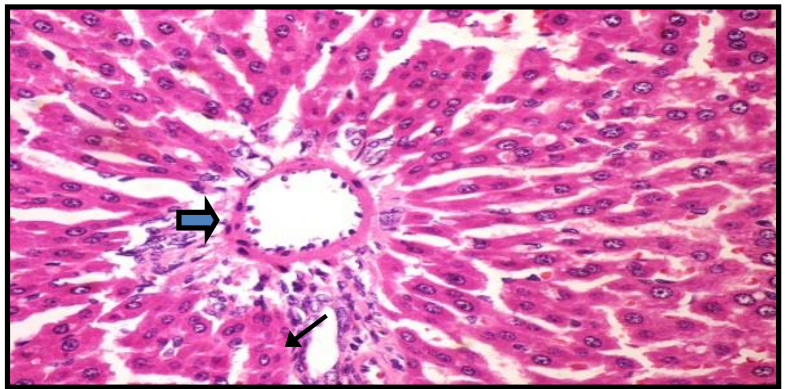

Photo (11): Liver of rat from group 5 (Prickly pear seeds 7.5\%) showing normal portal tract with normal bile duct (arrow) and hepato portal blood vessel (arrow head) (H\&E X 400).

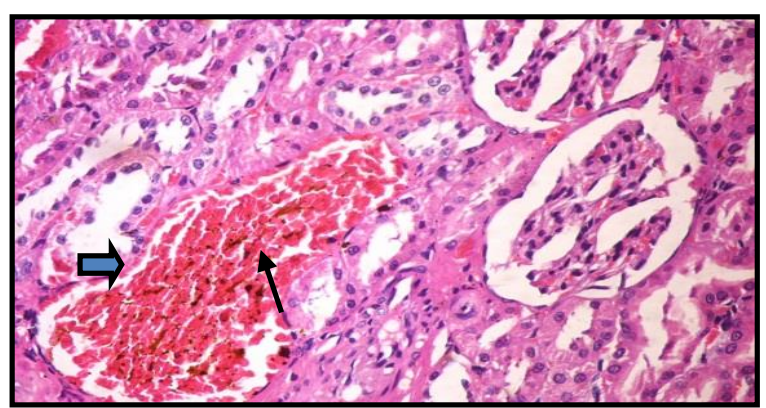

Photo (13): Kidneys of rat from group 1 (Control negative) showing apparently healthy glomeruli (arrow) and renal tubules (arrow head) (H\&E X 400).

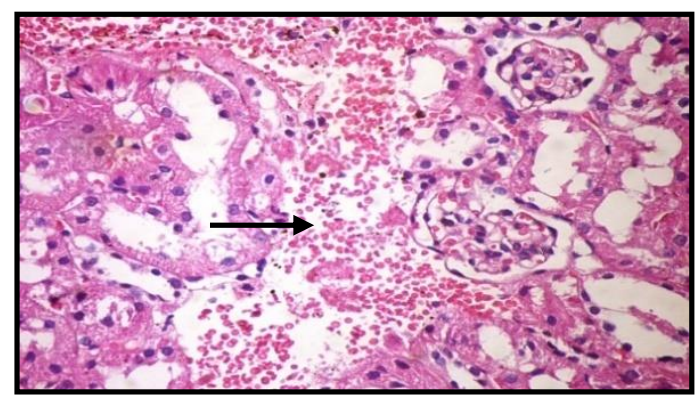

Photo (15): Kidneys of rat from group 3

(Marrow seed 7.5\%) showing diffuse areas of hemorrhage (arrow) (H\&E X 400).
Photo (14): Kidneys of rat from group 2 (Control positive) showing congestion of the interstitial blood vessel (arrow) (H\&E X 400).

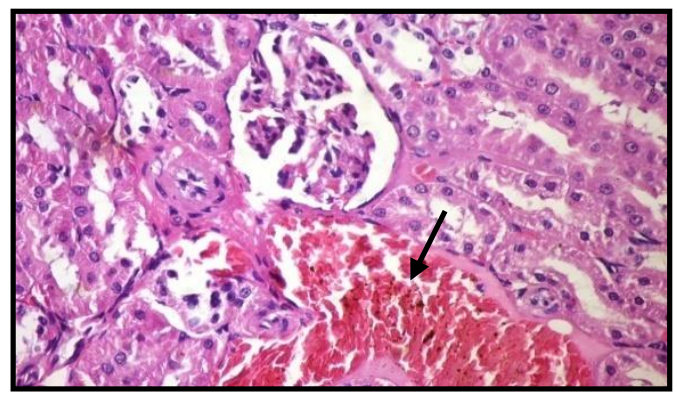

Photo (16): Kidneys of rat from group 4 (Lettuce seeds 7.5\%) showing congestion of the interstitial blood vessel (arrow) (H\&E X 400). 


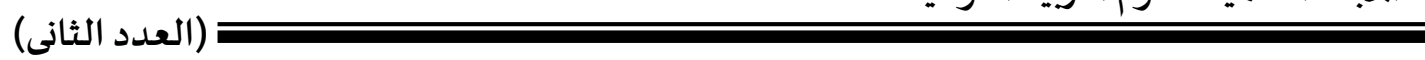

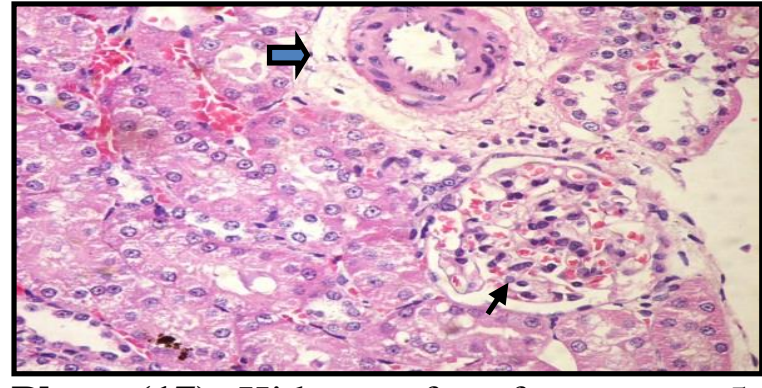

Photo (17): Kidneys of rat from group 5 (Prickly pear seeds 7.5\%) showing congestion of the glomerular capillaries' (arrow) and dilatation of interstitial blood vessel with per vascular edema (arrow head) (H\&E X 400).

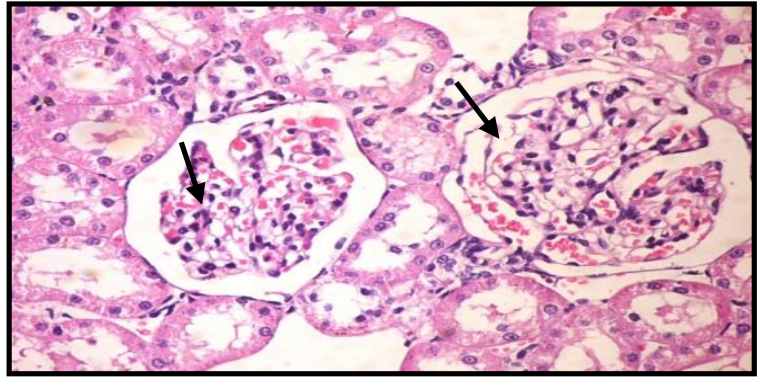

Photo (18): Kidneys of rat from group 6 (Mixture of all seeds 7.5\%) showing vacuolated glomerular epithelial cells (arrows) (H\&E X 400). 


\section{References}

Abuelgassim, A.O.I, and Al-showayman, S.I (2012). The effect of pumpkin (Cucurbita pepo L.) seeds and L-arginine supplementation on serum lipid concentrations in atherogenic rats. Afr. J. Tradit. Complement Altern. Med. 9(1):131-7.e Collection.

Baraham, D. and Trinder, P. (1972). Determination of uric acid. Analyst, 97:142.

Bartles, J.; Bohmer, M. and Heirli, C. (1972). Determination of creatinine. Clin. Chem. Acta, 37:193.

Baynes, J.W. and Thorpe, S.R. (1999). Role of oxidative stress in diabetic complication: a new perspective on an old paradigm, Diabetes, 48: 19.

Belfield, A. and Goldberg, D.M. (1971). Revised enzyme assay for serum phenyl phosphatase activity using 4-amino-antipyrine. 12, 561-573.

Benjamin, M. (1992). A study of the effects of Cucurbita Pepo seeds on kidney excretion from physiological chemistry laboratory. College of physicians and surgeons, Columbia University; Communicated by R.Perrl.

Brave, E.; Contafora, A.; Calabvini, A. and Ortu, G. (1994). Why prefer the golden Syrian hamster (Mesocricetus auratus) to the Westar rat in xperimental studies on plasma lipoprotein metabolism? Comp. Bio. Chem. Physio. 107 (B) :347-2ss.

Callias C. (2007). Les alicaments dans la lutte contre l'hypercholestérolémie. Bull. Soc. Ens. Neuch. Sci., 30:1-18.

Campbell, J.A. (1963). Methodology of protein evaluation .RAG Nutri, Document R.10m Led. 37 June Meeting New York.

Carleton, H. M.; Drumy, R. A. B.; Wallington E. A. and Cameron R. (1976). Histological Technique. 4th Edition. Oxford University Press. Lond. 108nnnnn.

Charles, C. Allain, Lucy, S.; Poon, C S. G.; Chan, W. R. and Paul, C. Fu. (1974). Enzymatic determination of total serum cholesterol. Clinical Chemistry, 20: 470-475.

Devi, R. and Sharma, D. K. (2004). Hypolipidemic effect of different extracts of Clerodendron colebrookianum Walp in normal and highfat diet fed rats. J. Ethnopharmacol, 90:63-68.

Ennouri, M.; Fetoui, H.; Bourret, E.; Zeghal, N. and Attia, H. (2006). Evaluation of some biological parameters of Opuntia ficus indica. 1. Influence of a seed oil supplemented diet on rats. Bioresource Technology, 97. (12): 1382-1386.

Fawcett, J. K. and Soctt, J. E. (1960). Determination of urea. J.Clin. Path.13:156-159.

Fnedewaid, W.T. (1972). Determination of HDL, Clin Chem., 18:499. Jacobs, N.J. 
Fossati, P. and Prencipe, L. (1982). Serum triglycerides determined calorimetrically with an enzyme that produces hydrogen peroxide CHEM. 28/10, 2077-2080.

Gordon, T. and Amer, M. (1977): Determination of HDL. J, 63:707

Hegsted, D.; Mills, R. C.; Mills, C. A.; Elvehjem, and Hart, E. B. (1941): Choline in the nutrition of chicks. J. Biol. Chem., 138:459-466.

Jowhary, H.; Kargar, H.; Faramarzi, A. and Mahmoudi, S. (2013).Effect of hydroalcoholic extract of lactuca sativa seeds on biochemical factors of cardiovascular diseases and formation of arthrosclerosis platelets in rabbits International Journal of Biology, Pharmacy and Allied Sciences (IJBPAS), 2(2): 314-324.

Kim, H. Y. Jeong, da M.; Jung, H. J.; Jung, Y. J.; Yokozawa, T. and Choi, J. S. (2008). Hypolipidemic effects of sophora flavescens and its constituents in poloxamer 407-induced hyperlipidemic and cholesterol-fed rats. Biol. Pharm. Bull., 31:73-78.

Kiple, K. and Kriemhild, O. (2000): The Cambridge World History of Food. New York: Cambridge University Press, 1801.

Kwon, K.C.; Verma, D.; Singh, N.D.; Herzog, R. and Daniell, H. (2013). Oral delivery of human biopharmaceuticals, autoantigens and vaccine antigens bioencapsulated in plant cells. Advanced Drug Delivery Reviews, 65(6): 782-799.

Larsen, K. (1972). Creatinine coloremitic kinetic method. J. of Clin. Chem., (41):209.

Lee, R.D and Nieman, D.C (1996). Nutritional Assessment, 2nd, Ed. Mosby, Missoun, USA.

Leo, D.E.; Abreu, M.M. B. D.; Pawlowska, A. M.; Cioni, P. L. and Braca, A. (2010). Profiling the chemical content of Opuntia ficusindica flowers by HPLC-PDA-ESI-MS and GC/EIMS analyses. Phytochemistry Letters, 3, (1): 48-52.

Lida, Y.; Mehrdad, M. and Mehran, M. (2013). The effect of hydro alcoholic extract of lettuce on blood parameters in Mice. Research Journal of Biological Sciences, 8: (2) 42-45.

Margarita, Hernández-Urbiola.; Esther, Pérez-Torrero.; Mario, E.; Rodríguez-García (2011). Chemical analysis of nutritional content of prickly pads (Opuntia ficus indica) at varied ages in an organic harvest. 26; 8(5):1287-95.

Mehmet, M. Ö. and Fahad, Y. A. (2011): Nutritive value and chemical composition of prickly pear seeds (Opuntia ficus indica L.) growing in Turkey. Int. J. Food. Sci. Nutr. 62(5):533-6.

Michelle, K. and Demand, M. (2014). http://healthyeating.sfgate. com /marrow-vegetable-3357.html.

Muller, A. (1964). Vitamin mixture. J. Biol. Chem., 20: 150 - 305. 
Ncibi, S.; Othman, M.B.; Akacha, A.; Krifi, M.N. and Zorgui, L. (2008). Opuntia ficus indica extract protects against chlorpyrifos-induced damage on mice liver. Food and Chemical Toxicology, 46: 797-802.

Rachid, S. and Hassan T. (2007). Cholestérol, lipoprotéine et athérosclérose: de la biochimie à la physiopathologie. Les Technologies de Laboratoire, 2:4-11.

Ramadan, M. F. and Mörsel, J. T. (2003). Oil cactus pear (Opuntia ficusindica L.). Food Chemistry, 82, (3): 339-345.

Reeves, P.G.; Nielsen, F.H.; Fahey, G.C. and Ain Jr. (1993). Purified diets for laboratory rodents. Final report of the American Institute of Nutrition. AIN-76A rodent diet. J. Nutr. 123 (11):1939-51.

Reitman, S. and Frankel, S. (1957). Colorimetric method for aspartate and alanine aminotransferase. Am. J. Clin. Path., 28: 26.

Rodriguez-Fragoso, L.; Reyes-Esparza, J.; Burchiel, S. W.; HerreraRuiz, D. and Torres, E. (2008). Risks and benefits of commonly used herbal medicines in Mexico. Toxicology and Applied Pharmacology, 227, (1): 125-135.

Roy, S. E. (1970). Colorimetric determination of serum alkaline phosphates. Clin. Chem., 28: 26.

Snedecor, G. W. and Cochran W. G. (1967). Statistical Methods. (6th Ed.) Ames, Iowa: The Iowa State University Press. 593p.

Stintzing, F. C., Schieber, A., and Carle, R. (2001).Phytochemical and nutritional significance of cactus pear. European Food Research and Technology, 212(4); 396-407.

Trinder, P. (1969). Determination of glucose in blood using glucose oxidase with an alternative oxygen acceptor. Ann. Clin Biochem, 6: 24.

Wolfram, R.; Budinsky, A.; Efthimiou, Y.; Stomatopoulos, J.; Oguogho, A. and Sinzinger, H. (2003). Daily prickly pear consumption improves platelet function. Prostaglandins Leukotrienes and Essential Fatty Acids, 69, (1): 61-66. 